Journal of Agricultural Sciences
(Tarim Bilimleri Dergisi)

\title{
Impacts of Covid-19 Pandemic on Global Agriculture, Livelihoods and Food Systems
}

\author{
Surendran ARUMUGAM ${ }^{\mathrm{a} *}(\mathbb{D})$, Burhan OZKAN ${ }^{\mathrm{b} *} \mathbb{E}^{\mathbb{D}}$, Aravind JAYARAMAN $^{\mathrm{c}}(\mathbb{D})$, Prahadeeswaran MOCKAISAMY ${ }^{\mathrm{d}}$ \\ ${ }^{a}$ Centre for Agricultural and Rural Development Studies (CARDS), Tamil Nadu Agricultural University, Coimbatore-Tamil Nadu, INDIA \\ ${ }^{b}$ Department of Agricultural Economics, Faculty of Agriculture, Akdeniz University, TURKEY \\ ${ }^{c}$ Department of Agricultural Entomology, Amrita School of Agricultural sciences, Coimbatore-Tamil Nadu, INDIA

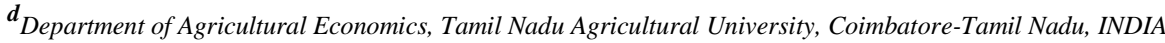

ARTICLE INFO

Article type: Review

*Corresponding Authors: suren.tnau@gmail.com / bozkan@akdeniz.edu.tr

Received: 22 May 2021 / 08 August 2021 / Accepted: 09 August 2021 / Online: 04 September 2021

\section{ABSTRACT}

The Covid-19 pandemic created a massive socio-economic panic in all sectors across the world. The agricultural sector is among the most important and crucial part of developing economics in the world. Therefore, the disruption in agriculture and food systems have significant impacts on the livelihood of a large section of people in the world. With this background, this paper performs an inclusive assessment of the effect of Covid-19 on agriculture and food systems in the major part of the impacted countries. A detailed review was made on reports, scientific publications, press releases, and organizational statements etc. This review addresses and highlights the direct impacts of Covid-19 on global food systems, market access for agricultural produce, food and nutritional security, global economy, labour availability and migration, agricultural input-output connectivity, initiatives to avert the crisis and importance of information technology (IT) system in agriculture. Further, this paper suggests mitigation and coping mechanisms that could be useful to improve and sustain the livelihoods of the people.

Keywords: Food security, Food reserve, Agricultural production, Socio-economic panic, Coronavirus, Price of agri-food products

(C) Ankara University, Faculty of Agriculture

\section{Introduction}

The world has to encounter an outbreak of the devastating novel coronavirus (Covid-19) that has been announced by the World Health Organization (WHO) as a global public health emergency (Wang et al. 2020) which causes the huge loss of human lives. The Covid-19 pandemic has been affecting the entire economic system of the globe including trade, labour migration, employment, inflation, supply chains, market access and food security (IFPRI 2020; Galanakis 2020). This resulted in reduction of purchasing power of households and availability of foods, for instance, the postharvest losses of fruits and vegetables around 10-15\% in developed countries and about 20-40\% in developing countries, higher in some specific crops caused food supply shocks (Kahramanoğlu et al. 2021).

The Covid-19 is unexpected since pandemics viz Spanish flu, Severe Acute Respiratory Syndrome (SARS), Polio, HIV, Zika virus, Ebola and the Middle East Respiratory Syndrome (MERS) are the latest outbreak in the world (Ceylan et al. 2020a; Saqr and Wasson 2020). However, the fatality due to pandemics was far more than the major wars (Adda 2016). For instance, in the last century, Spanish flu was a serious catastrophic pandemic, which causes 50 million death worldwide. During the time, risks were minimum because urbanization, globalization and movements between the countries were not as widespread as now and therefore, the chance of disease spread could be minimized as compared to the outbreak of recent Covid-19 (Shrestha et al. 2020).

Once the first Covid-19 case was identified, many developing countries imposed a state of emergency. The precaution measures including the stay at home, country-wide lockdown, quarantine and transport termination are highly challenging for many countries (OECD 2020c). Although, the lockdown permitting movement of the essential food commodities and was supposed to allow the agri-food supply chain to operate without any obstacles. However, the agri-food supply system faces a lot of challenges, including sporadic closure of local food markets and logistics barriers between cities, states and countries (Ceylan and Ozkan 2020a; Laborde 2020; Ivanov 2020). The agri-food distribution networks of all countries across the income scale have been highly disrupted, with strong negative consequences for the economically vulnerable communities (FAO 2020b; Galanaki 2020; Hobbs 2020; Stephens et al. 2020). 
In most of the countries, agri-food distribution network activities rely on migrant labours, who had left the cities during postlockdown, which leads to operational challenges including meats, fish weekly local and farmer's markets were closed in many places (Narayanan 2020; Mahendra Dev and Sengupta 2020; Stephens et al. 2020). In an early stage, the demand and supply of agri-food systems experienced a sense of confusion due to ambiguity and anxiety. However, more groceries stores, restaurants, hotels, schools, colleges and shopping malls were shut down and the departure of migrant workers resulted in demand for many commodities including milk, meats, fresh fruits, and vegetables dropped (Narayanan and Saha 2020a). Daily wages workers loss their work which results in food insecurity among the daily wage community (Swan 2020; Seth and Vishwanathan 2020). Also, the supplies of food have been interrupted on a large scale and poor people around the world will suffer from hunger if the local bodies, NGOs, governments and other associated organizations do not take any remedial actions (Torero 2020; The Guardian 2020). Although the stages of executing Covid-19 preventing measures may differ concerning the situation and have been considerably successful in controlling the outbreak of Covid-19. However, an inclusive assessment of the global pandemic effects is absent in the developing world. Given this situation, we attempted to review the consequences of Covid-19 on global agricultural and food systems. We mainly track and focused on unexpected risks, weaknesses and systemic shifts to understanding the short-term effects as well as those that may be long-lasting or permanent.

\section{Direct impacts in global food systems}

At the beginning of 2020, many countries have announced the lockdown and it has extended many times, a year after so the lockdown continuing in many parts of the countries due to the second and third wave of Covid-19. The lockdown means a complete loss of income for the daily wage workers, these represented $80 \%$ of the labour force in poor countries and $76 \%$ in subSaharan Africa (World Bank 2020). To overcome this crisis, the governments have taken certain possible measures to protect food security but worldwide food security has been exacerbated completely due to disruption in the food supply chain. In many poor countries, people die due to a lack of awareness, hunger and poverty. The extreme poverty level is projected to increase at a rapid rate (World Bank 2020). In order to ensure the stability of food production and supply, agricultural activities have been typically exempted from lockdown. However, the harvest of fruits and vegetables that are generally perishable had declined due to labour scarcity (Stephens et al. 2020; Phillipson et al. 2020). Also, the ongoing crisis is contributing to increasing logistical problems including the distribution of food to the right place at the right time (Held 2020; Poppick 2020).

Further, interruptions to agri-food marketing systems and price volatility would be the key factors for global food insecurity. During this pandemic, food price fluctuations are an obvious consideration in the underdeveloped and developing countries for both income of farmers and purchasing power of the consumers (Barrett 2020; Bellemare 2015). The marketing cost of agricultural commodities has been increased due to difficulties in logistics linked to the pandemic (Hahn 2020) and extend the wedge between farmers and consumer prices (Reardon et al. 2020; Lusk 2020; Reardon et al. 2020; Narayan and Saha 2020a). The food price increasing trends have been noted most often for perishables such as meat, fish, and vegetables (Akter 2020; Mogues 2020; Lele et al. 2020; de Paulo Farias and de Araújo 2020; Yu et al. 2020) and declines in other cases (Harris et al. 2020; Narayan and Saha 2020b). To overcome, (I) it is important to support losses of income from workers who are unable to purchase food products, (II) minimizing the wastage of fresh vegetables, fruits, and milk by permitting food transports from point of production to local markets or supermarkets.

\section{Food and nutritional security}

Recent reports indicate that nearly 140 million people will extremely suffer from food access, hunger, and food insecurity due to the Covid-19 pandemic (Barrett 2020; Laborde et al. 2020). A massive of them are in the sub-Saharan Africa region, where one out of five people were in hunger in 2019, which cruxes on the ability to acquire healthy and nutritious food (FAO, IFAD, UNICEF, WFP and WHO 2019). This delicate stability between agricultural productivity, poverty and food security particularly in the economically poor sections of the community (Hajra and Ghosh 2018; Priyadarshini and Abhilash 2020; CMIE 2020). During the lockdown, food prices were declining steadily. However, supply distractions due to the lockdown have upturned the movement of food prices (FAO 2020c). The changes in food supply and price are now alarming the food insecurity of people (De Sousa 2020). These burdens on food security triggered by the pandemic may not be affected all countries at the same vigour (Evelyn 2020). The condition is even more painful in East Africa, where the coronavirus is hampering efforts to fight against locust swarms (United Nations 2020).

Further, the lockdown prompted school closures are probable to lead to nutritional insecurity for children and pregnant women since the vast majority of poor people and children depend on cooked meals provided in the school by the governments (Alvi and Gupta 2020). The closure or diminished capacity of institutions could lead to enormously increasing mortality ratios among children under five because it is precluding 300 million school children from accessing their meals from the school on which they depend (United Nations 2020). Policy measures to alleviate the impacts of the Covid-19 pandemic on food and nutritional security must be prioritized (I) the areas with lower food production differently from those with the higher production; (II) support food social safety networks including food banks and school meals programs. 


\section{Agri-food prices and market access}

An unexpected lockdown across borders of countries and within countries has caused inputs supply, transports of agricultural products, and labour availability in the agri-food and marketing sector, which affected the food availability and prices globally (FAO 2020a). For example, in many African countries and India the agri-food commodity prices were increased by over $15 \%$ as compared with pre-Covid-19 periods (Hernandez et al. 2020). The Covid-19 has a substantial impact on agri-food systems, affecting predominately food supply and food security in the economically vulnerable region across the globe (FAO 2020c; Schmidt et al. 2020a; Alvi and Gupta 2020). The patrons are also influenced by the environments to storing food as well as sourcing the different food procurement choices due to supply chain interruptions, social distancing at the market place and reduction in grocery shops (Schmidt et al. 2020a).

Further, the retail and wholesale prices for agri-food products, including edible oils and pulses among other prices observed a sharp hike suddenly after the lockdown (Narayanan and Saha 2020a). However, there have been functional restrictions on restaurants, malls, supermarkets worldwide as a result agricultural commodities prices have been seen to be dropped by 20 percent at a later stage (Nicola et al. 2020). Supply chain interruption was a crucial factor for the short-run price instability but later the effects are less and stable (Cranfield 2020). The price stability measures including (I) increasing the communication networks and strengthening transport facilities would be the key factors in supporting food supply chain system, market access, and prices stability; (II) efforts to increase protected market yards with reduced procurement norms would enabling markets to function better during the pandemic situation. (III) It is important to have enough food reserve or storage facilities for the existing fruits and vegetables to meet the market demand. Fruits and vegetables are play a crucial role in human health during this pandemic. The postharvest handling practices must be strengthened by heat and pre-cooling treatments, curing, controlled atmosphere storage, film wrapping, edible coating materials, an optical sensor for grading, edible films etc.. (IV) It is also suggested to improve logistic and cold chain facilities during transports of the perishable commodities (Kahramanoglu et al. 2021). An increase in availability, and market access of agri-food products may stabilize the prices.

\section{Global Economy}

The Covid-19 also affecting the economic growth including industrial sector, agricultural production, trade and service sectors of the countries (Keogh-Brown and Smith 2008; Bloom et al. 2005; Ceylan et al. 2020a; Ceylan et al. 2020b). The global GDP contraction during 2020 was in the range of 3.0 to $7.5 \%$ and the prediction for the ensuing global GDP upturn in 2021 ranges from 2.8 to 5.8\% (IMF 2020; World Bank 2020; OECD 2020a). Likewise, global trade is expected to fall over by $5.3 \%$ in 2020 but trade volume is forecasted to increase by $8.0 \%$ in 2021 (James et al. 2021). However, the world investment report (Unctad, 2020) forecasts a decline in global foreign investment by up to $40 \%$ in 2020, with a further decrease by 5-10\% in 2021 (OECD 2020d). Further, the International Food Policy Research Institute (IFPRI) reported that the number of people living in extreme poverty increases by $20 \%$, or 150 million more people fall under the category due to the global economic contraction in 2020 (Laborde et al. 2021). In many countries, the food prices are expected to be more unstable than normal (Laborde et al. 2020; Ali et al. 2020; Reardon et al. 2020) and food insecurity is anticipated to increase considerably as a result of the Covid-19 (Ceylan and Ozkan 2020b; Laborde et al. 2021; Ali et al. 2020). Hence, (I) monetary authorities and central banks and have to promote emerging market economies; (II) national governments that have to adopt fiscal policy initiatives to stimulate the economics.

\section{Labour migration}

The most important evolving issue is labour availability in the agri-food sector. Covid-19 preventive measures in the different countries led to a loss of productive labours. There have been extensive constraints on international labour migration and worker programs that are critical to agricultural production in some sectors or that have caused bottlenecks. In the beginning, this was may not be a primary problem in the northern hemisphere countries. Although, the harvest of fruits and vegetables that are mostly perishable had declined due to shortages of labour (Phillipson et al. 2020; Stephens et al. 2020). Farmers who are more dependent on family labour appeared to be more resilient than those relying on external labour (Seleiman et al. 2020; Cortignani et al. 2020). The lockdown limitations not only caused agricultural productivity, input supply and marketability of farm products but also led to a revenue loss. The labour shortage affected the harvest of many agricultural commodities and allied sectors in different countries across the world (Seleiman et al. 2020; Cortignani et al. 2020).

Consequently, the agricultural production system including food grains, fruits and vegetables, livestock production is relatively labour-intensive. The disrupted or delayed cultivation of agricultural produce led to a loss of agricultural products, labour income, and food insecurity (Ceylan and Ozkan 2020b; Seleiman et al. 2020). Also, international transactions of the agricultural commodity were suffered due to labour scarcity, and rising prices appeared for exporting countries. While considering the situation of farmers, this pandemic led to both failure to transfer the agri-food products and to obtain inputs like fertilizers, seeds, chemical and livestock's feeds (Seleiman et al. 2020; Abouhatab et al. 2020). However, capital-intensive techniques are usually used in the developed countries for agricultural production, whereas low-income countries are mostly labour dependent for production. Hence, the agricultural production system and supply chain should be kept running with capital-intensive technologies and sufficient labour force to meet production challenges. Also, the working conditions that are safe for workers in order to avoid terrible consequences for future food security. 


\section{Agricultural inputs and outputs connectivity}

Farming is an input-intensive sector also each component of production can vary considerably in the agricultural production system. The inputs and connectivity including seeds, fertilizers, chemicals, irrigation equipment's and marketing of agricultural commodities were distrusted with respect to interruptions in transportation, delays in customs clearance, limitation of credit access, increased interest rates, and capital costs, which can lead to an increase the cost of the inputs. The increases in inputs cost and the perishability of agricultural products may lead to a huge loss to the farmers. The exiting situations retarded the distribution of food and agricultural inputs which created barriers in continuous food production and supply to markets (ILO 2020; FAO 2020d; FAO 2020e). Although different stages in a supply chain are strongly linked to each other in the agri-food production and processing sector, a small fault and delayed transports can prompt a "butterfly effect" and lead to a vast loss in agricultural production (FAO 2020e).

The agri-food sector is highly connected internationally, the shutdown or reduces the activity of ports and freight for agricultural goods led to supply chain disruptions (Ivanov 2020) have the potential to limit critical access to agricultural inputs and markets. Also, many countries have limited technologies and infrastructure to store food products including a lack of proper cold chain warehouses and storage godowns. This can be a major reason for food wastage and creates an impact on the resilience of the agri-foods sector (Balaji and Arshinder 2016; Raut et al. 2019). For instance, more than 18\% of the horticultural product's post-harvest storage losses are incurred annually due to limited infrastructure in India (GoI MOFPI 2020; Sivaraman 2016). The situations are jeopardizing and the limitation in the agricultural production system may have negative effects on food quality including freshness, food safety, affordability and access to the markets (FAO 2020e). During the pandemic situation, it is important to make every effort to move the gears of the agricultural production system. Also, innovative measures and adaptations have to be developed by the government for effective resilience. The existing situation also leaves little scope for identifying suitable domestic substitutes in order to address emerging domestic food security concerns due to Covid-19.

\section{Initiatives to avert the crisis}

Social security policy measures are important for the economically vulnerable community to mitigate the impact of the Covid19 pandemic. The government authorities in combination with the private organization must facilitate to keep the supply chain of agriculture more active and ensure to protect the agricultural and allied workers for continued food production (Hidrobo et al. 2020; Galanakis 2020). Table 1 listed Covid-19 impacts on the top five countries and their social protection measures.

Table-1: Top 5 Counties Incentives to Overcome Covid-19 Crises (Source: IMF 2021)

\begin{tabular}{|c|c|c|c|}
\hline No & Countries & Impacts & Nature of benefits \\
\hline 1. & USA & $\begin{array}{l}\text { - U.S. economy contracted around } 31.4 \% \\
\text { during } 2^{\text {nd }} \text { quarter of } 2020 \\
\text { - The unemployment rate was } 6.2 \% \text { in } \\
\text { February } 2021 \text {. }\end{array}$ & $\begin{array}{l}\text { - About } 5731 \text { Billion USD (about } 27.34 \% \text { of } 2020 \text { GDP) used for } \\
\text { public health, families assistance, unemployment benefits etc. }\end{array}$ \\
\hline 2. & India & $\begin{array}{l}\text { - GDP contracted sharply by } 24.4 \% \text { in } 2 \text { nd } \\
\text { quarter of } 2020 \text {. } \\
\text { - The advanced estimate for FY2020/21 GDP } \\
\text { growth to be }-8 \% \text {. }\end{array}$ & $\begin{array}{l}\text { - US } \$ 402.6 \text { Billion or } 15 \% \text { of the country's GDP (Akanksha 2021) } \\
\text { foregone or deferred revenues, credit provision to numerous } \\
\text { sectors, include free food grains; foods items, cooking gas and } \\
\text { cash transfers to lower-income households, wage support to low- } \\
\text { wage workers, postponement of rent and utility payments etc. }\end{array}$ \\
\hline 3. & Brazil & $\begin{array}{l}\text { - More than } 15 \text { million ( } 7 \% \text { ) people have been } \\
\text { infected and fatality rate is } 2.8 \% \text {. }\end{array}$ & $\begin{array}{l}\text { - Relief package about US } \$ 233.8 \text { billion (up to } 12 \% \text { GDP) used for health, } \\
\text { health supplies, income supports to households, unemployment's } \\
\text { compensation, small industries-tax reduction etc. }\end{array}$ \\
\hline 4. & France & $\begin{array}{l}\text { - France's GDP contracted by } 8.3 \% \text { in } 2020 \text {.In } \\
2021 \text {, the economy grew by } 0.4 \% \text { during the } \\
\text { first quarter compared to the previous } \\
\text { quarter. }\end{array}$ & $\begin{array}{l}\text { - To about US } \$ 211.7 \text { billion ( } 8 \% \text { of GDP), spent on measures } \\
\text { include health insurance, health supplies, social security, tax } \\
\text { payments for companies and accelerated refund of tax credits, } \\
\text { support for wages of workers, direct financial support for } \\
\text { microenterprises, postponement of rent and utility payments, } \\
\text { extension of expiring unemployment benefits until the end of the } \\
\text { lockdown etc. }\end{array}$ \\
\hline 5. & Turkey & $\begin{array}{l}\text { - GDP contracted by } 10 \% \text { y-o-y in } \mathrm{Q} 2 \text {, but } \\
\text { with a strong rebound in Q3, growth in } 2020 \\
\text { as a whole was }+1.8 \%\end{array}$ & $\begin{array}{l}\text { - Amount to US } \$ 74 \text { billion ( } 12.7 \% \text { of GDP) spend on measures } \\
\text { include loan guarantees to firms and households, tax deferrals for } \\
\text { businesses, equity injections into public banks, VAT has been } \\
\text { reduced on food commodities, a nationwide ban on employee } \\
\text { layoffs was in force until mid-May } 2021 \text { and short-term work } \\
\text { allowance system for all sectors was also extended through June, } \\
\text { as was the ban on layoffs, etc., }\end{array}$ \\
\hline
\end{tabular}


The FAO has suggested ensuring staple food availability on the basis of priority and the food products to be transported to demanding regions by minimizing restrictions on trade during the pandemic (FAO 2020b; WHO/FAO 2020). Further, (i) the specific recommendations including social protection along with emergency food assistance programs need to be expanded to keep people stay at home during the lockdown period. (ii) The instant payment support with the help of e-commerce can help the farmers to continue the agricultural practices during a state of emergency.

\section{Importance of IT in agriculture}

The information technology platform can help to communicate and share Covid-19 medication measures including protocols, research findings, news, which was found useful in one place of the world to the other. Local, national and international organizations are adopted social media and television platforms efficiently towards curbing the impact of the pandemic. Also, social media and networks system facilitates collective action, permit knowledge diffusion and encourage social support for households and communities (Rockenbauch and Sakdapolrak 2017; Ceylan and Ozkan 2020a). Also, the IT platform has become a key actor in all the sectors including food and agricultural marketing. It has been steadily growing since the late $2000 \mathrm{~s}$ and has now become significant market power and spread across the countries.

In recent years, the online food retailing sector has increasingly attracted scholarly attention, although a comprehensive understanding of the sector has not been achieved (De Reuver et al. 2018). For instance, the percentage of individuals purchasing food or groceries in the previous 12 months has increased from 5\% to 15\% in Europe (Eurostat 2019). In the European Union, overall total retail sales decreased by $17.9 \%$ however, the sales through mail orders / the Internet increased by $30 \%$ from April 2019 to 2020 (OECD 2020b). During this pandemic, in-store shopping in a grocery store would be supposed to be a risk, although consumer buying preference shifted to e-commerce / online shopping (Baker et al. 2020; Brick Meets Click 2020; Grashuis et al. 2020). The e-commerce and online delivery industry have been grown exponentially in many countries (Hobbs 2020; Information Resources Inc. 2020; Ceylan and Ozkan 2020b)). Hence, (i) to provide incentives to adopt digital technologies viz., mobile applications, social media platforms, drones, robots, television, and associated technologies to overcome the pandemic impacts. (ii) Also, it is important to quickly deploy these technologies in the communication, logistics, healthcare and other related sectors.

\section{Conclusions}

The Covid-19 outbreak is an unexpected challenge to the global health system. It was not purely a health issue, as to the disaster of millions of people around the world; the pandemic was a shattering event for economics, food securities, government policies, world trade and financial markets. Furthermore, covid-19 complex consequences targeted economically vulnerable communities across the world in impulsive ways, which require a better understanding, mitigation and coping strategies to overcome the consequences.

The major hazards to food security because of reduced household incomes combined with higher retail prices impose the consumer to cut down on the quantity and quality of food consumption. The important actions are necessary to keep the agricultural sector and supply chains working smoothly: (I) To sustain the demand for agricultural commodities, investments in transports and logistics must be improved with a wide network in the developing countries. (II) Digital marketing and the ecommerce industry need to be exhilarated with appropriate guidelines and incentives. (III) Small and medium enterprises working with raw materials for agriculture and allied sector also need special consideration so that the rural economy doesn't collapse. (IV) To avoid the scarcity of farm labour-policies must facilitate the availability of machinery through state and block bodies including Farmer Producer Organizations (FPOs) or custom hiring centres (CHCs) with appropriate incentives. (V) Vulnerable individual and communities including landless labourers, wage earners, migrant labourers and small farmers have been supported with free food grains; foods items, cooking gas and cash incentives.

To date, in many countries, food accessibility is severely affected followed by its availability compared with other food security dimensions. In the long run or post-pandemic era, food availability could be severely impacted if necessary action has not been taken by the concerned bodies. The governments must promptly plan to enhance food production by providing access to finance for the farmers and the low-income households to ensure economic activity. Also local markets need to structure adequate conditions for storing the products during the marketing, and the consumers are also recommended to apply cold storage at favourable conditions for preventing losses.

\section{References}

Abouhatab A, Boqvist S, Gräslund S, Hilbur Y \& Ortiz R (2020). SLUs global blog COVID-19 and food security reflections on Sweden's global contribution to Agenda 2030. http://blogg.slu.se/global-blog/2020/05/15/covid-19-and-food-security

Adda J'er^ome (2016). Economic activity and the spread of viral diseases: Evidence from high frequency data. The Quarterly Journal of Economics 131(2): 891-941

Akter S (2020). The impact of COVID-19 related 'stay-at-home' restrictions on food prices in Europe: findings from a preliminary analysis. Food Security 12: 719-725 (https://doi.org/10.1007/s12571-020-01082-3) 
Ali Z, Green R, Zougmoré R B, Mkuhlani S, Palazzo A, Prentice A M, Haines A, Dangour A D \& Scheelbeek P F D (2020). Long-term impact of West African food system responses to COVID-19. Nature Food 1-3

Alvi M \& Gupta M (2020). Learning in times of lockdown: how Covid-19 is affecting education and food security in India. Food Security 12: 793-796

Baker S R, Farrokhnia R A, Meyer S, Pagel M \& Yannelis C (2020). How Does Household Spending Respond to an Epidemic? Consumption during the 2020 COVID-19 Pandemic (No. 26949), NBER Working Papers, National Bureau of Economic Research, Inc. (2020)

Balaji M \& Arshinder K (2016). Modelling the causes of food wastage in Indian perishable food supply chain. Resour. Conserv. Recycl 114: $153-167$

Barrett C B (2020). Actions now can curb food systems fallout from COVID-19. Nature Food: 1-2

Bellemare M F (2015). Rising food prices, food price volatility, and social unrest. American Journal of Agricultural Economics 97(1): 1-21

Bloom E V, De Wit M J \& Carangal San Jose (2005). Potential Economic Impact of an Avian Flu Pandemic on Asia, https://www.thinkasia.org/handle/11540/2165

Ceylan R F \& Ozkan B (2020a). The Economic Effects of Epidemics: From SARS and MERS to COVID-19. Research Journal in Advanced Humanities 1(2): 21-29

Ceylan R F \& Ozkan B (2020b). Assessing Impacts of COVID-19 on Agricultural Production and Food Systems in the World and in Turkey, Gaziantep University Journal of Social Sciences 2020, Special Issue 472-485

Ceylan R F, Ozkan B \& Mulazimogullari E (2020a). Historical evidence for economic effects of COVID-19. Eur J Health Econ 21: 817-823

Ceylan R F, Ozkan B \& Mülazimogulları E (2020b). The Effects of Pandemic Diseases On The World Economy, The Journal of Social Economic Research 21(1): 1-10

CMIE (2020). Consumer Sentiments Decline in November. Centre for Monitoring Indian Economy Pvt Ltd. Dated $10^{\text {th }}$ December, 2020. Available at. https://www.cmie.co m/kommon/bin/sr.php?kall=warticle\&dt=2020-12-10\%2015:11:53\&msec=790

Cortignani R, Carulli G \& Dono G (2020). COVID-19 and labour in agriculture: Economic and productive impacts in an agricultural area of the Mediterranean. Italian Journal of Agronomy 15(2): 172-181

Cranfield J A L (2020). Framing consumer food demand responses in a viral pandemic, Canadian Agricultural Economics Society 68: 151156

De Paulo Farias D and de Araújo FF (2020). Will COVID-19 affect food supply in distribution centers of Brazilian regions affected by the pandemic? Trends in Food Science \& Technology

De Reuver M, Sørensen C \& Basole R C (2018). The digital platform: a research agenda

De Sousa A (2020). Tracking COVID-19. Bloomberg News. Retrieved from https://www.bloomberg.com/graphics/2020-coronavirus-dash/

Eurostat (2019). Survey on ICT (information and communication technology) usage in households and by individuals. E-commerce statistics for individuals. Retrieved from: https://ec.europa.eu/eurostat/web/digital-economy-and society/data/database

Evelyn K (2020). It's a racial justice issue: Black Americans are dying in greater numbers from Covid-19. The Guardian. Retrieved from https://www.theguardian.com/world/2020/apr/08/its-a-racial-justice-issueblackamericans-are-dying-in-greater-numbers-from-covid-19

FAO (2020a). Migrant workers and the COVID-19 pandemic. Food and Agriculture Organization of the United Nations (FAO), PP: 5. https://doi.org/10.4060/ca8559en. ISBN: 978-92-5-132386-1

FAO (2020b) COVID-19 and the risk to food supply chains: how to respond? Food and Agriculture Organization of the United Nations (FAO) Available: https://doi.org/10.4060/ca8388en

FAO (2020c) Value chain report no-1, June, 2020

FAO (2020d). Policy responses to keep input markets flowing in times of COVID-19. http://www.fao.org/3/ca8979en/CA8979EN.pdf. Accessed on May 8, 2020

FAO (2020e). Responding to the impact of the COVID-19 outbreak on food value chains through efficient logistics. http://www.fao.org/3/ca8466en/CA8466EN.pdf. Accessed on Apr. 24, 2020

FAO, IFAD, UNICEF, WFP, \& WHO (2019). The state of food security and nutrition in the world (SOFI) 2019. Safeguarding against economic slowdowns and downturns. Rome: FAO. Retrieved from https://www.wfp.org/publications/2019-statefood-security-and-nutrition-worldsofi-safeguarding-against-economic

Galanakis C M (2020). The food systems in the era of the coronavirus (COVID-19) pandemic crisis. Foods 9: 523

GoI MOSPI (2020). Sustainable development goals national indicator framework progress report 2020 (version 2.1). Ministry of statistics and programme implementation, government of India. Available at. http://mospi.nic.in/sites/default/files/publicatio n_reports/SDGProgressReport2020.pdf

Grashuis J, Skevas T \& Segovia M S (2020). Grocery Shopping Preferences during the COVID-19 Pandemic, Sustainability 12: pp.5369

Hahn W (2020). Livestock, Dairy, and Poultry Outlook, LDP-M-312. U.S. Department of Agriculture, Economic Research Service

Hajra R \& Ghosh T (2018). Agricultural productivity, household poverty and migration in the Indian Sundarban Delta. Elementa: Science of the Anthropocene 6, 3. https:// doi.org/10.1525/elementa.196

Harris J, Depenbusch L, Pal A A, Nair R M \& Ramasamy S (2020). Food system disruption: initial livelihood and dietary effects of COVID19 on vegetable producers in India. Food Security: 1-11

Held L (2020). Food Distribution 101: What happens when the food supply is disrupted by a pandemic. Civil Eats. Retrieved from https://civileats.com/2020/04/15/food-distribution-101-what-happens-when-the-foodsupply-is-disrupted-by-a-pandemic/

Hernandez M, Kim S, Rice B \& Vos R (2020). IFPRI's new COVID-19 Food Price Monitor tracks warning signs of stress in local markets. International Food Policy Research Institute. Accessed from https://www.ifpri.org/blog/ifpris-new-covid-19-food-price-monitor-trackswarning-signs-stress-local-markets

Hidrobo M, Kumar N, Palermo T, Peterman A \& Roy S (2020). Gender-sensitive social protection. A critical component of the COVID-19 response in low- and middle-income countries. International Food Policy Research Institute (IFPRI) Brief. Available at. https://ebrary.ifpri.org/utils/getfile/collection/p15738coll2/id/1 33701/filename/133912.pdf

Hobbs J E (2020). Food supply chains during the COVID-19 pandemic, Can. J. Agric. Econ./Revue canadienne d'agroeconomie, 68 : pp. 171 $176,10.1111 /$ cjag. 12237

IFPRI (2020). International Food Policy Research Institute. South Asia blogs and resources on COVID-19. Available: http://southasia.ifpri.info/2020/05/08/covid-19-blog-series-launch/

ILO (International Labour Organization) (2020). COVID-19 and the impact on agriculture and food security [Online]. https://www.ilo.org/wcmsp5/groups/public/---ed_dialogue/---sector/documents/briefingnote/wcms_742023.pdf. Accessed on Apr. 24, 2020 
IMF (2020). World economic outlook, April 2020: the great lockdown. International Monetary Fund, Washington, DC

IMF (2021). International monetary funds. Policy response to Covid-19, https://www.imf.org/en/Topics/imf-and-covid19/Policy-Responsesto-COVID-19

Information Resources Inc. (2020). COVID-19 Impact - Consumer Spending Tracker for Measured Channels, https://www.iriworldwide.com/IRI/media/Library/2020-05-15-IRI-BCG-COVID-Global-Consumer-Spend-Tracker.pdf

Ivanov D (2020). Predicting the impacts of epidemic outbreaks on global supply chains: a simulation-based analysis on the coronavirus outbreak (COVID-19/SARS-CoV-2) case. Transp. Res. Part E 136, 101922. https://doi.org/10.1016/j.tre.2020.101922

James K, Jackson, Martin A. Weiss, Andres B. Schwarzenberg, Rebecca M. Nelson, Karen M. Sutter, Michael D. Sutherland (2021). Global Economic Effects of COVID-19. Congressional Research Service. R46270 Updated May 7, 2021, https://crsreports.congress.gov

Kahramanoğlu İ, Kannan RR, Serhat U, Turgut A, Murat H, Volkan O, Mehmet AA \& Chunpeng W (2021). Improving the safety and security of fruits and vegetables during COVID-19 pandemic with postharvest handling, Critical Reviews in Food Science and Nutrition, DOI: 10.1080/10408398.2021.1935703.

Keogh-Brown M R \& Smith R D (2008) The economic impact of SARS: how does the reality match the predictions? Health Policy 88 (1): $110-120$

Laborde D (2020). Food Export Restrictions during the Covid-19 crisis. International Food Policy Research Institute https://public.tableau.com/profile/laborde6680\# !/vizhome/ExportRestrictionsTracker/FoodExportRestrictionsTracker;.

Laborde D, Martin W \& Vos R (2021). Impacts of COVID-19 on global poverty. Food security and diets. Agricultural Economics (Early view). https://doi.org/10.1111/agec.12624

Laborde D, Martin W, Swinnen J \& Vos R (2020). COVID-19 risks to global food security. Science, 369(6503), 500-502. https://doi.org/10.1126/science.abc4765

Lele U, Bansal S \& Meenakshi J V (2020). Health and Nutrition of India's Labour Force and COVID-19 Challenges. Economic \& Political Weekly 55 (21): 13

Lisheng W, Yiru W, Dawei Y \& Qingquan L (2020). Review of the 2019 novel coronavirus (SARS-CoV-2) based on current evidence. Int J Antimicrob Agents. DOI: https://doi .org/ 10.1016/j.ijantimicag.2020.105948

Lusk J (2020). Meat and egg prices following the COVID-19 outbreak. Blogpost. Retrieved from http://jaysonlusk.com/blog/2020/4/5/foodsales-and-prices-following-covid-19-outbreak

Mahendra Dev S, \& Sengupta R (2020). Covid-19: Impact on the Indian Economy, Indira Gandhi Institute of Development Research. Mumbai Working Papers, Indira Gandhi Institute of Development Research, Mumbai, India. Unctad (2020), World Investment Report 2020: International Production beyond the Pandemic, United Nations Publications, Geneva

Mogues T (2020). Food Markets During COVID-19. Special Series on Covid-19. Washington DC: International Monetary Fund. Downloaded on 08/03/2020 from https://www.imf.org/ /media/Files/Publications/covid19-special-notes/en-special-series-on-covid-19-food-marketsduring-covid-19.ashx

Narayan S \& Saha S (2020a). One step behind: The government of Indian and agricultural policy during the COVID-19 lockdown. Review of Agrarian Studies (Forthcoming)

Narayanan S (2020). Food and agriculture during a pandemic: Managing the consequences. Blog published by Ideas for India. https://www.ideasforindia.in/topics/agriculture/food-and-agriculture-during-a-pandemic-managing-theconsequences.html

Narayanan S \& Saha S (2020b). Urban food markets and the lockdown in India. Working Paper No. 2020-017, Indira Gandhi Institute of Development Research

Nicola M Z, Alsafi C, Sohrabi A, Kerwan A, Al-Jabir \& Iosifidis C (2020). The Socio-Economic Implications of the Coronavirus and COVID19 Pandemic: A Review. Int. J. Surg. DOI: https://doi.org/10.1016/j.ijsu.2020.04.018

OECD (2020a). OECD Economic Outlook. June 2020 Preliminary version. OECD Publishing, Paris. https://doi.org/10.1787/0d1d1e2e-en.

OECD (2020b). E-commerce in the time of COVID-19, OECD Policy Responses to Coronavirus (COVID-19), 7 October 2020

OECD (2020c). OECD Policy Responses to Coronavirus (COVID-19), Thethe territorial impact of COVID-19: Managing the crisis across levels of government, Updated 10 November 2020

OECD (2020d). OECD Policy Responses to Coronavirus (COVID-19), Coronavirus (COVID-19): SME policy responses, Updated 15 July 2020

Phillipson J, Gorton M, Turner R \& Shucksmith M (2020). The COVID-19 pandemic and its implications for rural economies. Sustainability 12(10): 3973. DOI: $10.3390 /$ su12103973

Poppick L (2020). The effects of COVID-19 will ripple through food systems. Scientific American. Retrieved from https://www.scientificamerican.com/article/the-effects-of-covid-19-will-ripple-through-food-systems/

Priyadarshini P \& Abhilash P C (2019). Promoting tribal communities and indigenous knowledge as potential solutions for the sustainable development of India. Environmental Development 32, 100459. https://doi.org/10.1016/j. envdev.2019.100459

Raut R D, Gardas B B, Narwane V S \& Narkhede B E (2019). Improvement in the food losses in fruits and vegetable supply chain-a perspective of cold third party logistics approach. Operations Research Perspectives 6, 100117. https://doi.org/10.1016/j. orp.2019.100117

Reardon T, Bellemare M F \& Zilberman D (2020). How COVID-19 may disrupt food supply chains in developing countries. In COVID-19 and Global Food Security, edited by J. Swinnen, and J. McDermott IFPRI Washington DC: 78-80

Reardon T, Mishra A, Nuthalapati C S R, Bellemare M F \& Zilberman D (2020). Covid-19's disruption of India's transformed food supply chains. Economic and Political Weekly 55(18): 18-22

Saqr M \& Wasson B (2020). COVID-19: Lost opportunities and lessons for the future. Int. J. Health Sci. 14: 4-6

Schmidt M (2020). Corona and resource resilience-is efficiency still a desirable goal? Sustainability Management Forum. Nachhaltigkeits Management Forum 28: 73-75. doi: 10.1007/s00550-020-00493-2

Seleiman M, Selim S \& Cezar J F (2020). Will novel Coronavirus (COVID-19) pandemic impact agriculture, food security and animal sectors? Bosicence Journal 36(4): 1315-1326. DOI: 10.14393/BJ-v36n4a2020-54560

Seth A \& Vishwanathan V (2020). What Covid-19 Means to Us' Voices from the Indian Hinterland. The India Forum. (Accessed 1 May 2020)

Shrestha N, Muhammad YS, Osman U, Modasser H K, Ajlina K-M, Uyen-Sa DT N, Mahdi B, Robert W, Nasrin A, Diana C, KHh. Md N, Rafdzah A Z, Ubydul H (2020). The impact of COVID-19 on globalization, One Health, Volume 11, 2020, 100180, ISSN 2352-7714, https://doi.org/10.1016/j.onehlt.2020.100180

Sivaraman M (2016). Government's Role in India's Ailing Cold Storage Sector. Centre for Public Policy Research. Available at. https://www.cppr.in/wp-content/uploads/201 6/12/Government\%E2\%80\%99s-Role-in-India\%E2\%80\%99s-Ailing-Cold-Storage -Sector.pdf 
Stephens E C, Guillaume M, Mark van W \& Jagadish Timsinad, Val S (2020). Editorial: Impacts of COVID-19 on agricultural and food systems worldwide and on progress to the sustainable development goals. Agricultural Systems 183 (2020) 102873, https://doi.org/10.1016/j.agsy.2020.102873

Swan (2020). 21 Days and Counting: COVID-19 Lockdown, Migrant Workers, and the Inadequacy of Welfare Measures in India, Stranded Workers Action Network (SWAN). Azim Premji University, Bengaluru, India

The Guardian (2020). Coronavirus could double number of people going hungry | World news. Available: https://www.theguardian.com/world/2020/apr/09/coronavirus-could-double-number-of-peoplegoing-hungry

Torero M (2020). Without food, there can be no exit from the pandemic. Countries must join forces to avert a global food crisis from COVID19. Nature 580, 588-589. https:// doi.org/10.1038/d41586-020-01181-3

United Nations (2020). Policy brief: the impact of COVID-19 on food security and nutrition. Available at. https://unsdg.un.org/resources/policy-brief-impact-covid-1 9-food-security-and-nutrition

World Bank (2020) Global Economic Prospects, June 2020. World Bank, Washington, DC. Accessed from http://hdl.handle.net/10986/33748

Yu X, Liu C, Wang H \& Feil J H (2020). The impact of COVID-19 on food prices in China: evidence of four major food products from Beijing, Shandong and Hubei Provinces. China Agricultural Economic Review 12 (3): 445-458

(C) 2021 by the authors. Licensee Ankara University, Faculty of Agriculture, Ankara, Turkey.

This article is an open access article distributed under the terms and conditions of the Creative

Commons Attribution (CC BY) license (http://creativecommons.org/licenses/by/4.0/). 